\title{
Rapid assessment of Wreathed Hornbill Aceros undulatus (Aves: Bucerotidae) populations and conservation issues in fragmented lowland tropical forests of Arunachal Pradesh, India
}

\author{
C. Murali Krishna ${ }^{1}$, Kuladip Sarma ${ }^{2} \&$ Awadhesh Kumar ${ }^{3}$ \\ ${ }^{1,2,3}$ Department of Forestry, North Eastern Regional Institute of Science \& Technology (Deemed University), Nirjuli, Papumpare \\ District, Arunachal Pradesh 791109, India \\ Email: ${ }^{1}$ murali7murali@gmail.com, ${ }^{2}$ kldpsarma306@gmail.com, ${ }^{3}$ tpileatus@gmail.com (corresponding author)
}

\begin{abstract}
A rapid assessment of Wreathed Hornbills, their distribution and abundance was carried out in fragmented lowland tropical forests of Lower Dibang Valley District, Arunachal Pradesh, northeastern India from October 2010 to April 2011 using the total count method. A total of $62 \mathrm{~km}$ distance was covered on foot to survey four study sites: Horupahar, Delo, Koronu and Injunu. Nine flocks of 172 hornbills were sighted. Aceros undulatus flock size ranged from 8-38 individuals with a mean of about 19.1 \pm 2.6 . Illegal logging, hunting for bushmeat and other body parts (feathers, beak etc.) for decorating the head gear and house interiors by the local tribals were observed as the major threats to the species in the study areas.
\end{abstract}

Keywords: Aceros undulatus, encounter rate, habitat encroachment, illegal logging, local hunting.

Date of publication (online): 26 November 2012

Date of publication (print): 26 November 2012

ISSN 0974-7907 (online) | 0974-7893 (print)

Editor: Shumpei Kitamura

Manuscript details:

Ms \# 02969

Received 18 October 2011

Final received 23 July 2012

Finally accepted 14 October 2012

Citation: Krishna, C.M., K. Sarma \& A. Kumar (2012). Rapid assessment of Wreathed Hornbill Aceros undulatus (Aves: Bucerotidae) populations and conservation issues in fragmented lowland tropical forests of Arunachal Pradesh, India. Journal of Threatened Taxa 4(14): 3342-3348.

Copyright: () C. Murali Krishna, Kuladip Sarma \& Awadhesh Kumar 2012. Creative Commons Attribution 3.0 Unported License. JoTT allows unrestricted use of this article in any medium for non-profit purposes, reproduction and distribution by providing adequate credit to the authors and the source of publication.

Acknowledgements: The authors express their sincere thanks to the PCCF-Wildlife, Itanagar for giving us necessary permission to carry out our research, and Mr. Umesh Kumar, Divisional Forest Officer, Mehao Wildlife Sanctuary for his valuable logistic support during the field work. Grateful thanks are also due to Director, NERIST and Dr. C.L. Sharma, Associate Professor \& Head, Department of Forestry, NERIST, Arunachal Pradesh for their administrative supports. We also would like to thank Dr. Aparajita Datta, Nature Conservation Foundation (NCF) for clearing the doubts regarding the species identification and distribution. Also, we would like to thank Mr. Raju Barthakur, Assistant professor, NERIST for keeping the paper free from grammatical errors. Last but not the least; we would like to thank the field assistants Biron J. and Agomena for helping us in the field and NRDMS, DST, Government of India for providing financial assistant to carried out this work.

urn:Isid:zoobank.org:pub:956F430A-F3AE-4339-A951-C248C9460EAC

\section{OPEN ACGESS | FREE DOWNLOAD}

Many species of hornbills are under the threat of extinction because they are specialised with regard to habitat, food and nesting sites. They play a very important role in the forest ecosystem as seed dispersers (Kinnaird 1998; Whitney \& Smith 1998; Kitamura et al. 2008; Balasubramanian et al. 2011). Nine species of hornbills have been recorded from India, of which five species are recorded from the tropical forests of Arunachal Pradesh (Datta 1998; Selvan 2010). Among these five species, the Wreathed Hornbill Aceros undulatus, also known as the Bar-pouched Wreathed Hornbill (Images $1 \& 2$ ), is threatened by illegal selective logging, habitat encroachment and local hunting pressure in unprotected tropical forestlands in Lower Dibang Valley District of Arunachal Pradesh (Kumar et al. 2011).

The distribution of the A. undulatus ranges from northeastern India, Bangladesh, Bhutan, Brunei Darussalam, Cambodia, Indonesia, Lao People's Democratic Republic, Malaysia, Myanmar, Thailand and Viet Nam (BirdLife International 2009). In general, hornbills feed mostly on figs. However, A. undulatus is more of a generalist frugivore when compared with the other species of hornbills such as the Great Pied and Brown Hornbill (Datta \& Rawat 2003). Hornbills are widely hunted by the Adi and Idu Mishmi tribals of Arunachal Pradesh for bushmeat. Hornbill body parts such as beak and feathers are also used in traditional culture as headgear decorations (Solanki et al. 2004; Riba 2012), and parts are even displayed in the houses by the tribal population as trophies (Datta 2002). The local communities of Mehao have a long tradition of hunting which is a major threat to wildlife in the study area (Chetry et al. 2010). Aceros undulatus is listed as Least Concern under IUCN (BirdLife International 


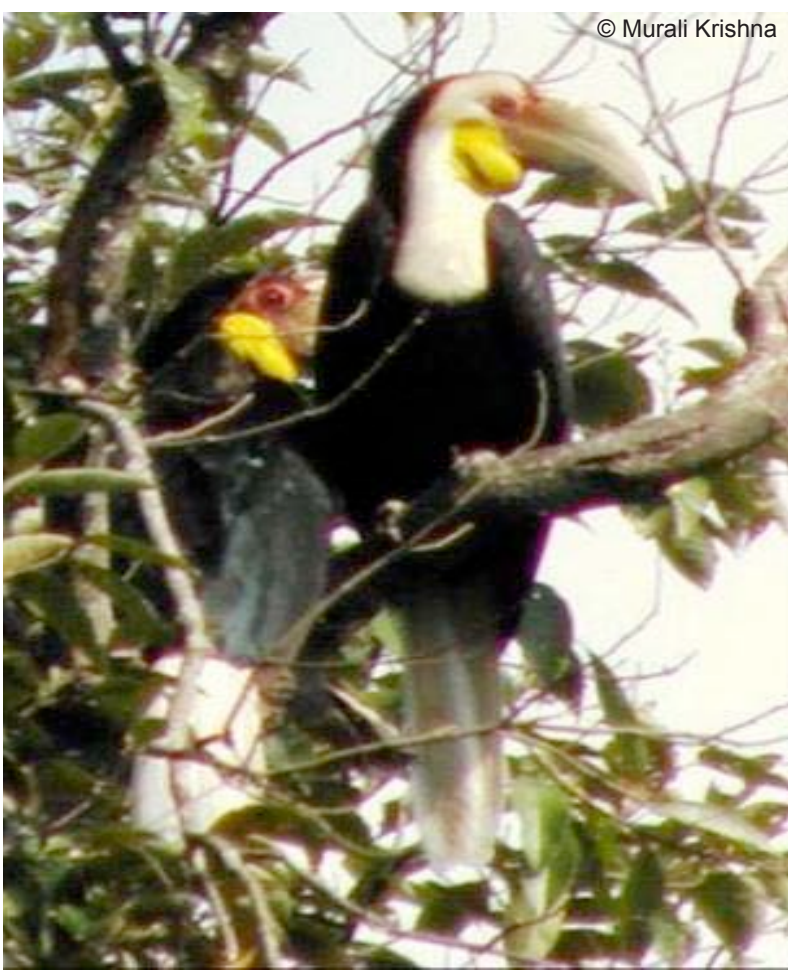

Image 1. Male Wreathed Hornbills on resting.

2012) and as Schedule-I species of the Indian Wildlife (Protection) Act (1972) (Anonymous 1994).

The present study tried to assess the current population status and conservation issues of A.undulatus in fragmented lowland tropical forest of Lower Dibang Valley District of Arunachal Pradesh and also to highlight the importance of species conservation.

\section{Materials and Methods}

Study area: Four sites with fragmented forests were chosen namely Delo (95054'E \& $28^{\circ} 02^{\prime} \mathrm{N}$ ), Koronu (95 $\left.55^{\prime} \mathrm{E} \& 28^{\circ} 01^{\prime} \mathrm{N}\right)$, Horupahar (95 $53^{\prime} \mathrm{E} \&$ $\left.28^{\circ} 01{ }^{\prime} \mathrm{N}\right)$ and Injunu $\left(95^{\circ} 51^{\prime} \mathrm{E} \& 28^{\circ} 02^{\prime} \mathrm{N}\right)$ which lie adjacent to the Mehao Wildlife Sanctuary of Lower Dibang Valley District of Arunachal Pradesh (Image 3) with an elevation range between 200-275 m. The study sites do not have fixed boundaries which made it difficult for us to calculate the area of each study site and all the sites are inhabited. The fragmented forests of the study area consisted of tropical semievergreen vegetation dominated by tree species such as Neolamarckia cadamba, Ailantus grandis, Bischofia javanica, Duabanga grandiflora, Dipterocarpus macrocarpus, Erythrina suberosa, Ficus sp. and do

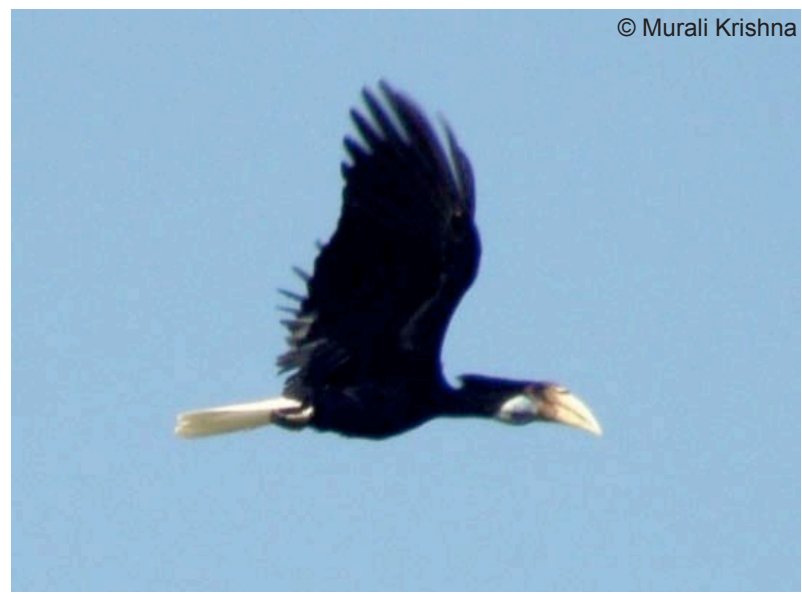

Image 2. Female Wreathed Hornbills in flight

not fall under any category of protection. Adis and Idu Mishmis are the major tribes who dominate the study area and generally cultivate agricultural crops like Mustard Sinapis alba, Maize Zea mays, Ginger Zingiber officinale and Turmeric Curcuma longa for their livelihood, in open fragmented areas which
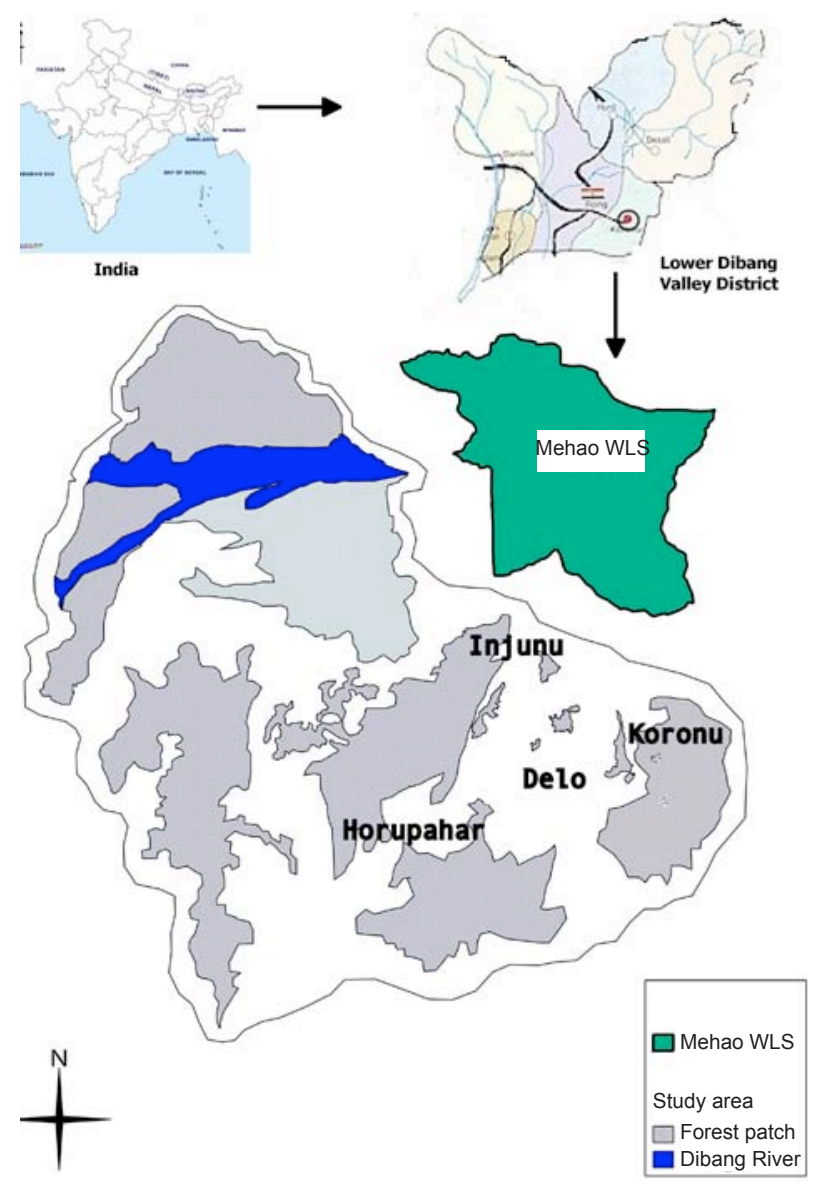

Image 3. The locations of the study sites. 
were created after selective logging and habitat encroachment.

Population survey and estimation: The study was conducted from October 2010 to April 2011. Total count method was employed to conduct rapid population assessment as it is the best method for accessing flock forming birds (Colin et al. 1998; Javed \& Rahul 2002). All the birds found roosting on trees along the trail during the survey were taken into account and flying birds were ignored. Repeat surveys were conducted on each survey month (October, December 2010 and February, April 2011) for three subsequent days between 05:30-11:00 hrs (Appendix 1). An assumption was made before conducting the survey: "That the flocks were never recounted on the same day of the survey". A total of $62 \mathrm{~km}$ of distance was covered in all four study sites $14 \mathrm{~km}$ in Horupahar, $19.5 \mathrm{~km}$ in Delo, $15 \mathrm{~km}$ in Koronu and $13.5 \mathrm{~km}$ in Injunu. All the individuals of Aceros undulatus sighted along the trail were recorded for total flock size as well as tree species on which they were sighted. The flocks sighted were grouped together by placing different flocks of almost same flock size or a same group on consecutive survey days. In case an area had two or more flocks with the same flock size, then the flocks were placed randomly on the data sheet for population analysis. The flock size and the number of flocks sighted on each survey were noted and the mean size of the flock and mean flock numbers were calculated at the end of the survey.

Estimation of vegetation parameters: Vegetation analysis was done by counting the number of trees in the trails followed. A total of nine trails were used for collecting the data. Trails were laid randomly in the study area and the length of the each trail was maintained constant at $1 \mathrm{~km}$ with a width of $20 \mathrm{~m}$. Girth at breast height $(\mathrm{GBH})$ was not recorded during the time of the study as all the flocks that we encountered were observed on the trees having $\leq 150 \mathrm{~cm} \mathrm{GBH}$, also only large trees above $100 \mathrm{~cm}$ GBH were left after the clearing of the area for the purpose of agriculture. Also, we recorded a number of cut stumps in the trails in order to evaluate the illegal logging pressure of the area. Fig trees that had fallen on the trail were also counted.

Questionnaire survey: A rapid questionnaire survey was employed and 18 people were interviewed in the study sites to get their quick response on the methods
Table 1. Details of Wreathed Hornbill flocks sighted

\begin{tabular}{|c|c|c|c|}
\hline Study area & $\begin{array}{l}\text { Average No. of } \\
\text { flock recorded } \\
\text { in study site }\end{array}$ & $\begin{array}{l}\text { Average } \\
\text { flock size }\end{array}$ & $\begin{array}{l}\text { Mostly sighted on } \\
\text { tree species }\end{array}$ \\
\hline \multirow{2}{*}{ Delo } & \multirow{2}{*}{02} & 24 & Ficus sp. \\
\hline & & 12 & Bischofia javanica \\
\hline \multirow{3}{*}{ Horupahar } & \multirow{3}{*}{03} & 14 & Ficus sp. \\
\hline & & 11 & Ficus sp. \\
\hline & & 20 & Ficus sp. \\
\hline \multirow{3}{*}{ Koronu } & \multirow{3}{*}{03} & 21 & Canarium sp. \\
\hline & & 34 & Ficus sp. \\
\hline & & 20 & Bischofia javanica \\
\hline Injunu & 01 & 16 & Bischofia javanica \\
\hline Total & 09 & 172 & \\
\hline Average & & 19.1 & \\
\hline
\end{tabular}

Table 2. Habitat status of study area

\begin{tabular}{|c|l|c|c|c|}
\hline & Area & $\begin{array}{c}\text { No. of trees } \\
\text { recorded } \\
\text { per } \mathbf{k m}\end{array}$ & $\begin{array}{c}\text { No. of fig } \\
\text { plants per } \\
\mathbf{k m}\end{array}$ & $\begin{array}{c}\text { No. of cut } \\
\text { stumps per } \\
\mathbf{~ k m}\end{array}$ \\
\hline 1 & Delo & 44.0 & 2.0 & 1.8 \\
\hline 2 & Horupahar & 40.6 & 2.3 & 2.4 \\
\hline 3 & Koronu & 36.6 & 3.2 & 1.7 \\
\hline 4 & Injunu & 20.6 & 3.3 & 1.5 \\
\hline
\end{tabular}

Table 3. Details of hunting of Wreathed Hornbills by locals

\begin{tabular}{|c|c|c|c|c|}
\hline $\begin{array}{c}\text { Name of } \\
\text { the Village }\end{array}$ & $\begin{array}{c}\text { No. of } \\
\text { hunters } \\
\text { Inter- } \\
\text { viewed }\end{array}$ & $\begin{array}{c}\text { Approximate } \\
\text { no. of hornbills } \\
\text { hunted during } \\
\text { migratory } \\
\text { season }\end{array}$ & $\begin{array}{c}\text { Local guns } \\
\text { preferred } \\
\text { for hunting }\end{array}$ & $\begin{array}{c}\text { Catapults } \\
\text { preferred } \\
\text { for } \\
\text { hunting }\end{array}$ \\
\hline Delo & 6 & $15-20$ & 5 & 1 \\
\hline Horupahar & 6 & $15-20$ & 6 & Nil \\
\hline Koronu & 3 & $10-15$ & 3 & Nil \\
\hline Injunu & 3 & $10-15$ & 2 & 1 \\
\hline Total & 18 & $50-70$ & 16 & 2 \\
\hline
\end{tabular}

of hunting, number of hornbills hunted every season, preferences of hornbill species for hunting and use pattern of hornbill such as for cultural, bushmeat or trade. The survey was conducted mainly during the evenings when the locals were free from work and only men were interviewed in the study as females were never involved in hunting.

\section{Results}

Population status: We estimated a minimum of 172 individuals of Aceros undulatus in nine flocks 
during the study (Table 1) in particularly logged and fragmented forest areas. The average flock size was estimated as $19.1 \pm 2.6$, ranging from 8-38 individuals.

Conservation status: Vegetation and logging: Tree density was highest in Delo ( 44 trees $/ \mathrm{km}$ trees followed by Horupahar ( 40.6 trees $/ \mathrm{km})$, Koronu (36.6 trees $/ \mathrm{km}$ ) and Injunu (20.6 trees $/ \mathrm{km})$ (Table 2). Fig tree density was highest in Injunu (3.3 individuals $/ \mathrm{km}$ ) and was lowest in Delo (2 individuals $/ \mathrm{km}$ ). Illegal selective logging was commonly observed in the study area for timber, firewood, house construction materials, etc. Logging was highest in Horupahar (2.4 cut stumps/ $\mathrm{km}$ ) followed by Delo (1.8 cut stumps $/ \mathrm{km})$, Koronu (1.7 cut stumps $/ \mathrm{km}$ ) and Injunu (1.5 cut stumps $/ \mathrm{km})$ was the least (Table 2; Images $4 \& 5$ ).

Hunting: According to the responses drawn from the local people through rapid interviews, overall 50-70 Aceros undulatus are hunted throughout their migratory period, i.e., in winter in the study sites (Table 3) which probably could be an over estimate. The number of hornbills hunted varied in each site ranging from 10-20 individuals. Most of the hornbills are hunted as a part of sport hunting and the meat of the bird is consumed as food. The hunted hornbill meat was never observed for sale in the local markets as it is usually shared within the family and community. The gizzard of the hornbill was used in some local medicines for curing stomach disorders. The feathers and skulls of the birds are used as decorative items in the houses by Idu Mishmis and Adis. Guns are preferred $(88 \%, \mathrm{n}=16)$ over catapults $(12 \%, \mathrm{n}=2)$ by the local people for hunting hornbills due to the high success rate (Image 6).

\section{Discussion}

Population: We estimated the minimum population as 172 individuals of 9 flocks in the study area. Though this may not indicate the exact population of the $A$. undulatus in the given area, still an estimate can be made. Finding the exact estimates of such nomadic flock forming birds is a difficult task. A. undulatus usually live in huge flocks both in breeding and nonbreeding seasons (Kinnaird \& O’Brien 2007). Flock size of upto 1000 individuals of $A$. undulatus was also recorded in Thailand's Khao Yai National Park (Poonswad \& Kemp 1993). However, the small flock size in the study area might be due to unavailability of food resources and hunting.

Effect of logging and fig tree density: The data that we collected during the study was very limited thus drawing assumptions based on it might be difficult to interpret. Datta (1998) stated that logging does not affect the distribution pattern of the species as they are nomadic in nature. Our results have also shown the same. Logging at a rapid phase in the study area has created huge gaps in the vegetation thus the hornbills were easily sighted (Image 7). Rijksen (1978) stated that fig densities determine the hornbill abundance of a given area. However, fig densities did not have any impact on the species as A. undulatus is a nomadic species and tend to travel large distances between feeding sites and the roosts during the breeding season (Leighton 1986). Mostly fig trees in the study area were used as roosting sites by the species. At times, observations were made where $A$. undulatus fed on the figs as well.

\section{Conservation issues}

Habitat fragmentation leads to accessibility of forest resources and thus facilitates easy hunting of wildlife species (Robinson et al. 1999). High degree of forest fragmentation due to anthropogenic practices such as selective logging, agricultural practices has deteriorated the forest quality in the present study areas

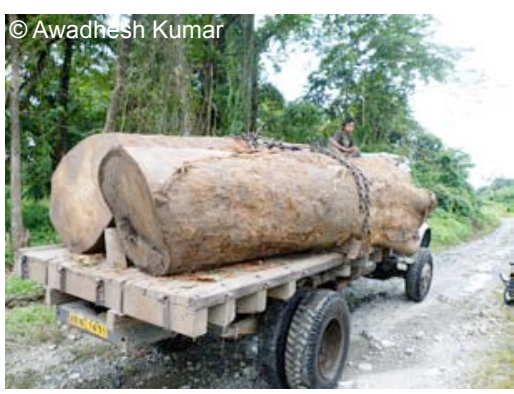

Image 4. Illegal logging in study area.

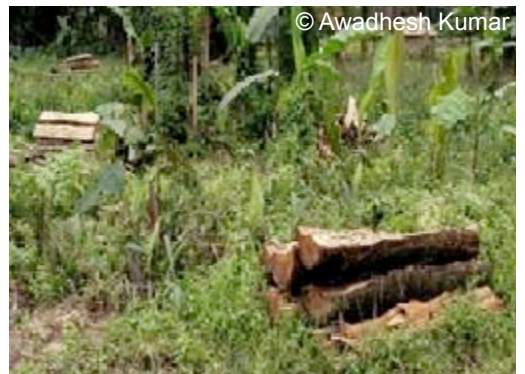

Image 5. Forest cutting for firewood

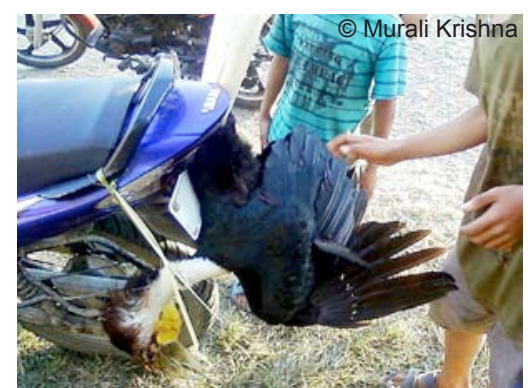

Image 6. Hunting of hornbill for food 


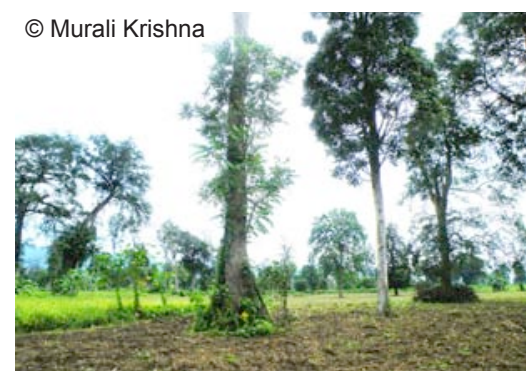

Image 7. Degraded open forest in study area

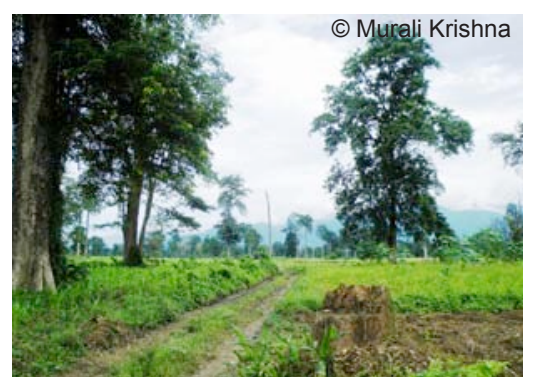

Image 8. Selective logging for timber

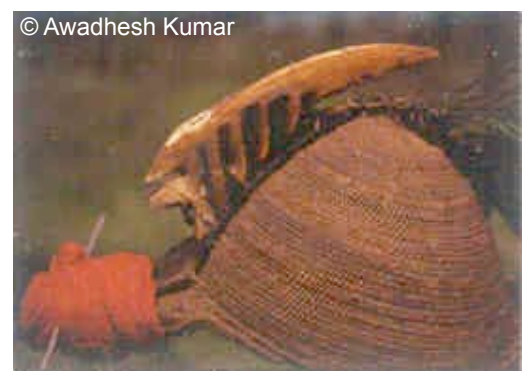

Image 9. Nyshi Headgear decorated by beak of Wreathed hornbill.
(Image 8). This led to easy sighting of hornbills for hunters making the species more vulnerable. Hornbill species are hunted for their casque and feathers (Rohit 2008). Mishmis and Adis usually hunt hornbills for meat and their body parts (skull, feathers, casque, etc.) and these are exhibited as trophies in their living room and also used in decorating their headgear. Buceros bicornis is the preferred hornbill species over Aceros undulatus for hunting in Arunachal Pradesh (Datta 2002; Kumar et al. 2011) due to their high demand in the local market for headgear decoration (Image 9). The beak of B. bicornis is mostly used to decorate the headgear of the Nyishi tribe. The only reason for targeting A. undulatus in the study area by the tribals is that, it is the only hornbill species found in the study area.

Based on the responses received from the villagers by comparing the past and present abundance of species, it was evident that $A$. undulatus population is declining in the area. It may be due to high hunting and habitat loss in the study sites. Habitat loss was observed due to increasing agricultural practices to cultivate cash crops such as Sinapis alba, Zea mays, Zingiber officinale and Curcuma longa in the study area (Images $10 \& 11$ ). In addition to agricultural practices, illegal logging of mature trees, which act as roosting sites for $A$. undulates, were also observed during the study period. The poor regeneration of plant species in Koronu and the absence of regeneration of the preferred tree species (Ficus sp.) in the other three sites could be the reason for the declining natural seed dispersers. Kitamura et al. (2008) stated that A. undulatus are primarily scatter dispersers during the day in the moist evergreen forest and act as key stone species for preserving the forest ecosystem. Balasubramanian et al. (2011) has supported this hypothesis by explaining the role of Indian Grey Hornbill in the regeneration of Santalum album in Tamil Nadu, India. Similarly, Whitney \& Smith (1998) also stated that hornbill densities in primary and secondary forests of central Africa suggested that they are important agents of seed dispersal in both habitats. Kinnaird (1998) also explained that the Red Knobbed Hornbills effectively dispersed seeds of several tropical trees thus influencing the initial fate of seeds in the regeneration process of the forests.

Logging and hunting, if continued in the same phase will definitely affect the population of $A$. undulatus leading to local possible extripation in the near future from the study area. So, certain measures have to be taken by the forest department and the government by bringing awareness among the local communities explaining to them the importance of hornbills for conservation and preservation of forest ecosystem in addition to ensuring a continuous supply of forest resources to the local inhabitants themselves. Thus, to conserve the hornbill on a sustainable basis, keeping the feeding and behavioural ecology of A. undulatus in mind, large areas of disturbed and fragmented lowland tropical forests in the study sites have to be restored with tree species which could fulfil the basic needs of the local society as well as wildlife in general and A. undulatus in particular. A. undulatus are more generalized feeders during the non-breeding season (Datta 2001; Datta \& Rawat 2003) and they can survive in human dominated landscape as per the general observations. Thus, the population of hornbills will stay least affected and will thrive in its migratory habitats in future. 


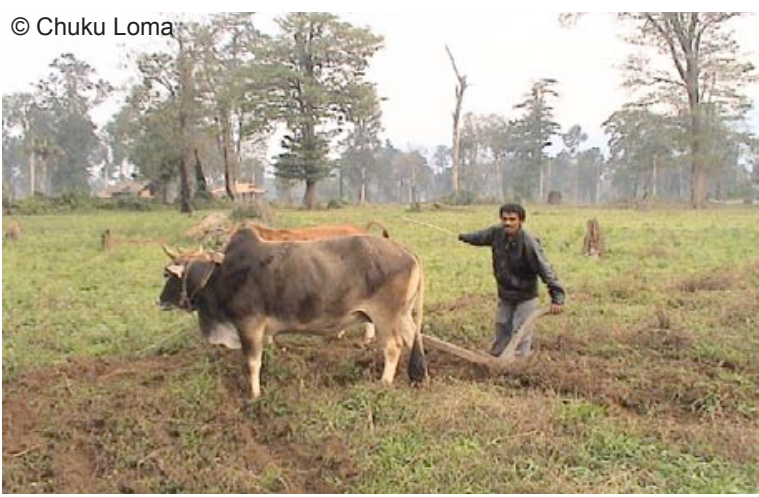

Image 10. Local people polughing his fild after cutting forest.

\section{REFERENCES}

Anonymous (1994). The Indian Wildlife Protection Act, 1972 (as amended upto 1993). 2nd Edition. Natraj Publishers, Dehra Dun, 158pp.

Balasubramanian, P., R. Aruna, C. Anbarasu \& E.S. Kumar (2011). Avian frugivory and seed dispersal of Indian Sandalwood Santalum album in Tamil Nadu, India. Journal of Threatened Taxa 3(5): 1775-1777.

BirdLife International (2012). Aceros undulatus. In: IUCN 2012. IUCN Red List of Threatened Species. Version 2011.2. <www.iucnredlist.org>. Downloaded on 20 January 2012

Chetry, D., R. Chetry, K. Ghosh \& A.K. Singh (2010). Status and Distribution of the Eastern Hoolock Gibbon (Hoolock leuconedys) in Mehao Wildlife Sanctuary, Arunachal Pradesh, India. Primate Conservation 25: 87-94.

Colin, B., M. Jones \& S. Marsden (1998). Expedition Field Techniques - Bird Surveys. Published by the Expedition Advisory Centre, Royal Geographical Society, London, 136pp.

Datta, A. (1998). Hornbill abundance in unlogged forest, selectively logged forest and a forest plantation in Arunachal Pradesh, India. Oryx 32(4): 285-294.

Datta, A. (2001). An ecological study of sympatric hornbills and fruiting patterns in a tropical forest in Arunachal Pradesh. PhD Thesis, Saurashtra University, Rajkot, India.

Datta, A. (2002). Status of hornbills and hunting among tribal communities in Eastern Arunachal Pradesh. Unpublished Report.

Datta, A. \& G.S. Rawat (2003). Foraging patterns of Sympatric Hornbills during the non-breeding season in Arunachal Pradesh, northeast India. Biotropica 35(2): 208-218.

Javed, S. \& K. Rahul (2002). Field methods for bird surveys. Bombay Natural History Society, Department of Wildlife Sciences, Aligarh Muslim University, Aligarh, and World Pheasant Association, South Asia Regional Office (SARO), New Delhi, India, 21-25pp.

Kinnaird, M.F. (1998). Evidence for effective seed dispersal by the Sulawesi Red-Knobbed Hornbill Aceros cassidix.

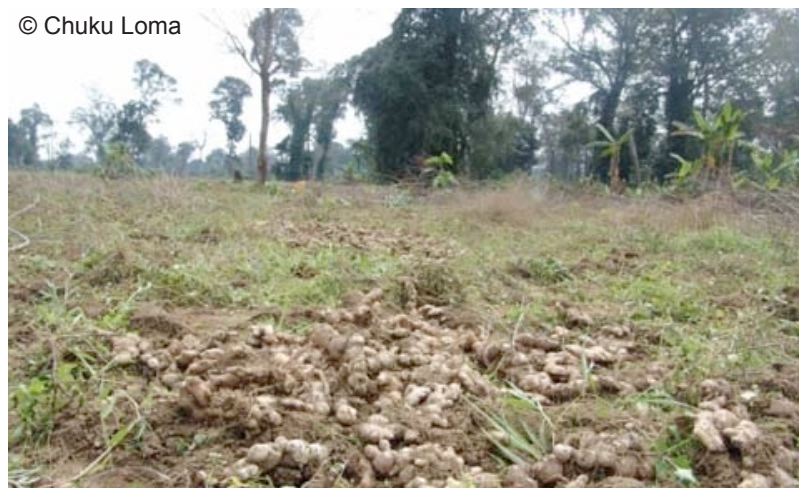

Image 11. Ginger crop cultivated in study area.

Biotropica 30(1): 50-55.

Kinnaird, M.F. \& T.G. O'Brien (2007). The Ecology \& Conservation of Asian Hornbills: Farmers of the Forest. University of Chicago press. pp143.

Kitamura, S., T. Yumoto, N. Noma, P. Chuailua, T. Maruhashi, P. Wohandee \& P. Poonswad (2008). Aggregated seed dispersal by wreathed hornbills at a roost site in a moist evergreen forest of Thailand. Ecological Research 23: 943-952.

Kumar, A., C.M. Krishna \& K. Sarma (2011). Impact of logging and fragmentation on population abundance of Wreathed Hornbill Aceros undulatus and Great Pied Hornbill Buceros bicornis and their conservation in lowland tropical forests of Eastern Arunachal Pradesh, northeast India. Abstract Published in proceedings, Status of Indian Birds and Their Conservation, SACON. Nov 2011.

Leighton, M. (1986). Hornbill social Dispersion: variations on a monogamous theme, pp. 181-196. In: Rubenstein, D. \& R.W. Wrangham (eds.). Ecological Aspects of Social Evolution. Blackwell Scientific Publications, Oxford.

Poonswad, P. \& A.C. Kemp (1993). Manual on the Conservation of Asian Hornbills. Hornbill Project Thailand. Bangkok, 513pp.

Rijksen, H.D. (1978). A Field Study of The Sumatran Orangutan (Pongo pygmaeus abelii, Lesson, 1827): Ecology, Behaviour \& Conservation. H. Veenman \& Zonen, Wageningen, Holland.

Riba, B. (2012). Aassessment of conservation efforts made for protection and conservation of hornbill species in Arunachal Pradesh, India. MSc Thesis, Department of Forestry, NERIST, Itanagar, Arunachal Pradesh, 32pp.

Robinson, J.G., K.H. Redford \& L. Bennett (1999). Wildlife harvest in logged tropical forests. Science 284: 595-596.

Rohit, N. (2008). Flight of the Great Hornbill. Red Panda Newsletter 1(3): 4.

Selvan, K.B.M. (2010). Survival of Great Pied Hornbills in Arunachal Pradesh. Current Sciences 99(5): 10.

Solanki, G.S., P. Cutia \& O.P. Singh (2004). Headgear- A cultural artefact and its implication on Biodiversity in Arunachal Pradesh. Arunachal University Research Journal 
Appendix 1. Showing the list of flocks sighted on different days of survey in different areas.

Delo

\begin{tabular}{|c|c|c|c|}
\hline Date & $\begin{array}{c}\text { No. of hornbill } \\
\text { groups observed }\end{array}$ & $\begin{array}{c}\text { Observed flock with number } \\
\text { of individuals }\end{array}$ \\
\hline 25.x.2010 & 1 & 12 & - \\
\hline 26.x.2010 & 1 & 12 & - \\
\hline 27.x.2010 & 2 & 11 & 26 \\
\hline 02.xii.2010 & 2 & 12 & 22 \\
\hline 03.xii.2010 & 2 & 16 & 26 \\
\hline 04.xii.2010 & 2 & 11 & 22 \\
\hline 06.ii.2011 & 2 & 11 & 23 \\
\hline 07.ii.2011 & 2 & 10 & 28 \\
\hline 08.ii.2011 & 1 & 10 & - \\
\hline 02.iv.2011 & 2 & 11 & 24 \\
\hline 03.iv.2011 & 1 & 12 & - \\
\hline 04.iv.2011 & 1 & 12 & - \\
\hline Mean & & 11.6 & 24.4 \\
\hline
\end{tabular}

\section{Koronu}

\begin{tabular}{|c|c|c|c|c|}
\hline Date & $\begin{array}{c}\text { No. of hornbill } \\
\text { groups observed }\end{array}$ & \multicolumn{3}{|c|}{$\begin{array}{c}\text { Observed Flock with number } \\
\text { of individuals }\end{array}$} \\
\hline 25.x.2010 & 3 & 20 & 32 & 20 \\
\hline 26.x.2010 & 3 & 21 & 33 & 19 \\
\hline 27.x.2010 & 2 & 21 & 38 & \\
\hline 02.xii.2010 & 3 & 22, & 34 & 20 \\
\hline 03.xii.2010 & 2 & 23 & 36 & \\
\hline 04.xii.2010 & 2 & 23 & & 20 \\
\hline 06.ii.2011 & 3 & 20 & 29 & 19 \\
\hline 07.ii.2011 & 2 & 21 & & 22 \\
\hline 08.ii.2011 & 3 & 21 & 34 & 18 \\
\hline 02.iv.2011 & 3 & 22 & 36 & 19 \\
\hline 03.iv.2011 & 1 & 20 & & \\
\hline 04.iv.2011 & 1 & 34 & & \\
\hline Mean & & 20.5 & 34 & 19.6 \\
\hline
\end{tabular}

\section{Horupahar}

\begin{tabular}{|c|c|c|c|c|}
\hline Date & $\begin{array}{c}\text { No. of hornbill } \\
\text { groups observed }\end{array}$ & \multicolumn{3}{|c|}{$\begin{array}{c}\text { Observed flock with number } \\
\text { of individuals }\end{array}$} \\
\hline 25.x.2010 & 2 & 14 & 16 & \\
\hline 26.x.2010 & 3 & 12 & 11 & 17 \\
\hline 27.x.2010 & 3 & 14 & 16 & 18 \\
\hline 02.xii.2010 & 3 & 11 & 14 & 21 \\
\hline 03.xii.2010 & 3 & 8 & 13 & 20 \\
\hline 04.xii.2010 & 1 & & & 23 \\
\hline 06.ii.2011 & 3 & 10 & 13 & 20 \\
\hline 07.ii.2011 & 1 & & 18 & \\
\hline 08.ii.2011 & 3 & 11 & 14 & 19 \\
\hline 02.iv.2011 & 2 & 12 & 14 & \\
\hline 03.iv.2011 & 3 & 11 & 16 & 21 \\
\hline 04.iv.2011 & 0 & 14 & 16 & \\
\hline Mean & & 11.4 & 14.5 & 19.8 \\
\hline
\end{tabular}

Injunu

\begin{tabular}{|c|c|c|}
\hline Date & $\begin{array}{c}\text { No. of hornbill } \\
\text { groups observed }\end{array}$ & $\begin{array}{c}\text { Observed flock with } \\
\text { number of individuals }\end{array}$ \\
\hline 25.x.2010 & 1 & 14 \\
\hline 26.x.2010 & 1 & 18 \\
\hline 27.x.2010 & 1 & 18 \\
\hline 02.xii.2010 & 1 & 16 \\
\hline 03.xii.2010 & 1 & 15 \\
\hline 04.xii.2010 & 1 & 17 \\
\hline 06.ii.2011 & 1 & 16 \\
\hline 07.ii.2011 & 1 & 14 \\
\hline 08.ii.2011 & 1 & 16 \\
\hline 02.iv.2011 & 1 & 17 \\
\hline 03.iv.2011 & - & 14 \\
\hline 04.iv.2011 & - & 18 \\
\hline Mean & & 16.1 \\
\hline
\end{tabular}

7(1): 35-44.

Whitney, K.D. \& T.B. Smith (1998). Habitat use and resource tracking by African Ceratogymna hornbills: implications for seed dispersal and forest conservation. Animal Conservation 1: 107-117. 